\title{
Molecular analysis of $\beta$-lactamases from four species of Streptomyces: comparison of amino acid sequences with those of other $\beta$-lactamases
}

\author{
Mats Forsman, ${ }^{*}$ Britta HägGStröm, Lena Lindgren and BengtÅke JaUrin $\dagger$ \\ Department of Cell- and Microbiology, National Defence Research Establishment, S-901 82 Umeå, Sweden
}

(Received 11 July 1989; revised 28 September 1989; accepted 16 October 1989)

\begin{abstract}
Genes encoding extracellular $\beta$-lactamases of Streptomyces badius, Streptomyces cacaoi, Streptomyces fradiae and Streptomyces lavendulae were cloned and mapped in Streptomyces lividans. DNA sequence analysis of the $\beta$ lactamase genes revealed a high overall $G+C$ content, ranging from 71 to $75 \mathrm{~mol} \%$, with a $G+C$ content of $95 \mathrm{~mol} \%$ at the third position of the codons for all four genes. The primary structure of the $\beta$-lactamases including their signal peptides was deduced. The four $\beta$-lactamases exhibited homology to each other and to class A $\beta$ lactamases from other bacterial genera. We suggest that Streptomyces $\beta$-lactamases are representatives of a superfamily of genes, from which class A $\beta$-lactamases of Gram-negative bacteria may have evolved.
\end{abstract}

\section{Introduction}

Gene structure analysis and the regulation of gene expression in the Gram-positive mycelial bacterium Streptomyces are of widespread interest. Streptomyces has a complex growth cycle with multiple morphological stages, making it useful for developmental studies. Bacteria from this genus also produce a large number of antibiotics and enzymes of which many are industrially important.

$\beta$-Lactamases (EC 3.5.2.6) of chromosomal or plasmid origin have been found in a large number of Grampositive and Gram-negative bacteria (Citri, 1971). Three evolutionarily distinct $\beta$-lactamase groups, classes A, B and $C$, have been proposed (Ambler, 1980; Jaurin \& Grundström, 1981). Examples of class A $\beta$-lactamases (penicillinases) are those from Staphylococcus aureus (Ambler, 1975), Bacillus licheniformis (Yamamoto \& Lampen, 1976), B. cereus type I enzyme (Thatcher, 1975) and the plasmid-encoded TEM $\beta$-lactamases (Ambler \& Scott, 1978; Sutcliffe, 1978). The $\mathrm{Zn}^{2+}$-requiring $B$. cereus type II enzyme (Hussain et al., 1985) belongs to class $\mathbf{B}$; class $\mathbf{C}$ enzymes comprise the chromosomally determined cephalosporinases from Gram-negative bacteria such as Escherichia coli (Jaurin \& Grundström, 1981) and Pseudomonas aeruginosa (Knott-Hunziker et al., 1982). Recently, a class $D$ group of oxacillinhydrolysing $\beta$-lactamases has been proposed, including

$\dagger$ This paper is dedicated to the memory of Dr Bengtåke Jaurin who died on 18 January 1990.

Abbreviation: ORF, open reading frame. the OXA-2 $\beta$-lactamase of Salmonella typhimurium (Dale et al., 1985) and the PSE-2 enzyme of $P$. aeruginosa (Huovinen et al., 1988).

The majority of Streptomyces strains produce extracellular $\beta$-lactamases (Ogawara, 1981). From an evolutionary aspect, it would be of interest to elucidate the molecular structure of Streptomyces $\beta$-lactamases, since they possibly represent ancestors of other $\beta$-lactamases (Ogawara, 1981). The primary structures of the $S$. albus G $\beta$-lactamase (Dehottay et al., 1987) and of an S. cacaoi $\beta$-lactamase (Lenzini et al., 1988) indicate that these enzymes are class $A$-lactamases.

To study transcription, secretion and evolutionary aspects of extracellular enzymes in Streptomyces, we have undertaken a molecular analysis of the extracellular $\beta$-lactamases of this genus. The genes for the $\beta$ lactamases of $S$. badius, $S$. cacaoi and $S$. fradiae have been cloned previously in S. lividans (Jaurin et al., 1988a) and the DNA sequence encoding the $S$. cacaoi enzyme has been established (Forsman et al., 1989). Here we report the primary structure of $\beta$-lactamases of $S$. badius, $S$. fradiae and $S$. lavendulae, and show that Streptomyces $\beta$-lactamases are representatives of a superfamily of genes from Gram-positive bacteria, from which it is possible that class A $\beta$-lactamases of Gram-negative bacteria have evolved.

\section{Methods}

Bacterial strains, plasmids, media and culture conditions. S. lividans 1326 (Lomovskaya et al., 1972) was used as the host for all Streptomyces 
DNA cloning work. For preparation of chromosomal DNA, $S$. lavendulae DSM 2014 was used. E. coli strains DH1 (Hanahan, 1983) and JM103 (Yanisch-Perron et al., 1985) were used as hosts for all $E$. coli DNA cloning work. Streptomyces plasmids pJAS01 (Jaurin \& Cohen, 1984) and pIJ487 (Ward et al., 1986) and the E. coli plasmid pACYC184 (Chang \& Cohen, 1978) have been described elsewhere. Plasmid pIJ4642 was kindly provided by Dr T. Kieser (John Innes Institute, Norwich, UK).

E. coli was cultivated at $37^{\circ} \mathrm{C}$ in LB medium and on LB agar plates (Bertani, 1951). Streptomyces was grown at $30^{\circ} \mathrm{C}$ in YEME medium (Bibb et al., 1977) and R2YE medium (Thompson et al., 1980) and on agar plates of these media; the liquid cultures were grown aerobically in a New Brunswick Scientific orbital shaker at 200 r.p.m. S. lividans containing pJAS01 or pIJ487 and its derivatives was grown on plates containing $50 \mu \mathrm{g}$ thiostrepton $\mathrm{ml}^{-1}$, and in liquid cultures containing $20 \mu \mathrm{g}$ thiostrepton $\mathrm{ml}^{-1}$. E. coli containing pACYCl84 or pIJ4642 and their derivatives was grown in the presence of chloramphenicol $\left(25 \mu \mathrm{g} \mathrm{ml}^{-1}\right)$. All standard manipulations of DNA were, if not otherwise stated, done as described by Maniatis et al. (1982).

Chemicals and enzymes. All chemicals were of the highest grade commercially available. Restriction endonucleases and DNA-modifying enzymes were purchased from Boehringer Mannheim and Pharmacia. All isotopes were purchased from Amersham. Nitrocefin was obtained from BBL. Nucleotide reagents for DNA sequencing were purchased from Pharmacia. Thiostrepton was a gift of E. J. Squibb \& Sons, New Brunswick, NJ, USA. Agaroses were purchased from FMC Corporation, and oligonucleotides were obtained from Symbicom (Umeå, Sweden).

Subcloning of the $S$. fradiae $\beta$-lactamase gene. The $S$. fradiae DSM $40063 \beta$-lactamase gene was previously cloned on a $\sim 4000 \mathrm{bp}$ DNA fragment (Jaurin et al., 1988a); before attempting to sequence the gene it was subcloned further. Plasmid $\mathrm{p} \beta \mathrm{F}-1$ containing pACYC184 DNA (Jaurin et al., 1988a) was digested with SphI, religated, and introduced into E. coli DH1. The resulting plasmid (Fig. $1 a$ ), denoted $\mathrm{p} \beta \mathrm{F}-1-184$, was isolated and purified.

To subclone the $\sim \mathbf{4 0 0 0}$ bp DNA fragment encoding $\beta$-lactamase activity in $S$. lividans (Jaurin et al., 1988 $a$ and Fig. $1 a$ ), p $\beta \mathrm{F}-1-184$ was digested either with BamHI and SphI or XbaI and SspI (Fig. 1a). Exonuclease III and $\mathrm{S} 1$-nuclease treatments at various times generated deletions from both directions, i.e. starting from BamHI or $\mathrm{XbaI}$, respectively, as described by Henikoff (1984). The ends were made blunt by Klenow treatment and the molecules were circularized using T4-DNA ligase, whereafter competent $E$. coli DH1 cells were transformed (Hanahan, 1983) with material from each time point. Chloramphenicol-resistant colonies were picked-out for each successive time interval and analysed by restriction enzyme digestion for the location of deletion breakpoints. A selected set of nested deletions from both directions were cut with EcoRI and ligated to EcoRI-digested pIJ487 (Ward et al., 1986). The ligation mixes were introduced into protoplasts of $S$. lividans by transformation, as described by Bibb et al. (1978), except that the protoplasts were spread as a $0.7 \%$ R2YE agar overlay on R2YE plates. After regeneration for $3 \mathrm{~d}$ at $30^{\circ} \mathrm{C}$, the cells were replicated onto R2YE plates containing $50 \mu \mathrm{g}$ thiostrepton $\mathrm{ml}^{-1}$. After growth for a further $3 \mathrm{~d}$, the thiostrepton-resistant colonies for each time point were screened directly for $\beta$-lactamase production by dropping nitrocefin, a chromogenic cephalosporin (O'Callaghan, 1973), onto the plates. The smallest insert expressing $\beta$-lactamase was $\sim 2000 \mathrm{bp}$ and originated by deletion from the BamHI site. This $\sim 2000$ bp fragment was further subcloned by utilizing the SalI site located $\sim 400 \mathrm{bp}$ from the left-end of the insert (Fig. $1 a$ ). The $\sim 1680$ bp $S a l$ I fragment of $\mathrm{p} \beta \mathrm{F}-1-184-\Delta 1$ (Fig. $1 a$ ) was cloned into the $X$ hoI site of pJASO1 in the host $S$. lividans. The resulting nitrocefinpositive recombinants confirmed that the complete $\beta$-lactamase gene of $S$. fradiae was included on the $\sim 1680$ bp Sall fragment. (a) $S$. fradiae $\beta$-lactamase gene

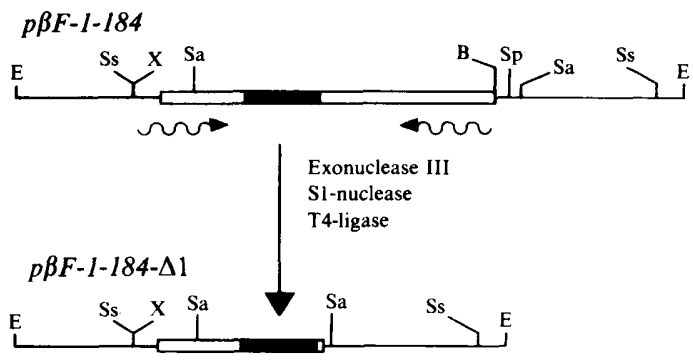

$\mathbf{l ~ k b}$

(b) S. lavendulae $\beta$-lactamase gene

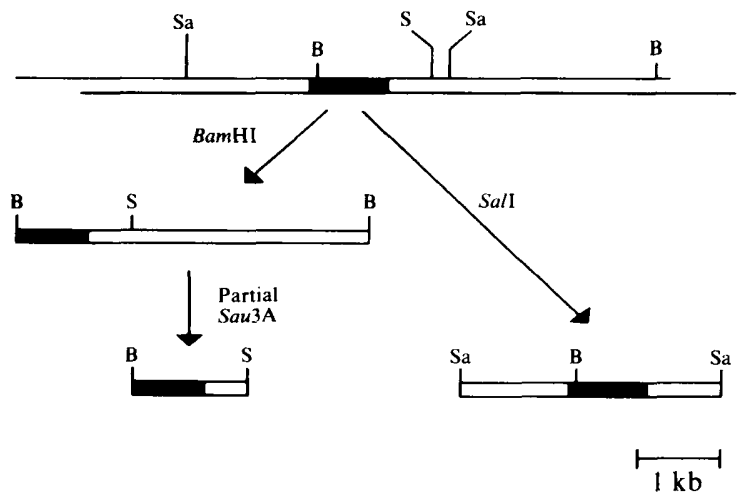

Fig. 1. (a) Subcloning of $S$. fradiae $\beta$-lactamase gene. Plasmid $\mathrm{p} \beta \mathrm{F}-1$ 184 , containing a $\sim 4000$ bp DNA insert encoding $\beta$-lactamase activity, was digested with BamHI and $S p h \mathrm{I}$ or $S s p \mathrm{I}$ and $X b a \mathrm{I}$, respectively, and subjected to exonuclease III digestion (wavy arrows). From the resulting deletion derivatives of $\mathrm{p} \beta \mathrm{F}-1-184$, the smallest clone mediating $\beta$-lactamase activity, denoted $\mathrm{p} \beta \mathrm{F}-1-184-\Delta 1$, was isolated. The $\sim 2000$ bp DNA insert of $p \beta F-1-184-\Delta 1$ was further subcloned by digestion with SalI, generating a $\sim 1680$ bp DNA fragment, that was ligated to XhoI-cleaved pJAS01. (See Methods for details.) (b) Cloning and subcloning of $S$. lavendulae $\beta$-lactamase gene. The gene was initially cloned on a $\sim 4300$ bp BamHI fragment and further subcloned to a $\sim 1400$ bp BamHI-Sau3A fragment. However, circumstantial evidence showed that the complete gene was not included on this subcloned fragment. Therefore, the $\beta$-lactamase gene of S. lavendulae was recloned from a SalI genomic library. A $\sim 3200$ bp SalI fragment, carrying the complete gene, was identified and cloned in pJAS01. (See Methods for details.) The filled boxes represent the location of $\beta$-lactamase genes of $S$. fradiae and $S$. lavendulae, respectively. Open boxes and double lines indicate chromosomal DNA. The restriction enzymes have been abbreviated as follows: B, BamHI; Sa, SalI ; S, Sau3A;Sp, SphI; Ss, SspI ; X, XbaI. Only relevant restriction sites are shown.

Cloning of the $S$. lavendulae $\beta$-lactamase gene. Chromosomal DNA of $S$. lavendulae, prepared as described by Hopwood et al. (1985), was digested with BamHI and ligated to BamHI-cleaved pJAS01. After introduction into $S$. lividans, as described above, about 12000 thiostrepton-resistant colonies were obtained. The recombinants were screened for $\beta$-lactamase production with nitrocefin. Plasmid DNA from two $\beta$-lactamase positive clones was purified and characterized by restriction enzyme mapping; both contained an identical $\sim 4300$ bp $B a m H I$ insert. These plasmids were transformed into $S$. lividans to 
demonstrate that the $\beta$-lactamase production obtained was mediated by plasmid DNA and not due to some rearrangement or mutation in the host.

Subcloning of the $S$. lavendulae $\beta$-lactamase gene. To subclone the $S$. lavendulae $\beta$-lactamase gene, the $\sim 4300 \mathrm{bp}$ BamHI fragment was purified from an agarose gel by electroelution and partially digested with Sau3A. The DNA was separated by electrophoresis on a $1.2 \%$ preparative GTG agarose gel. DNA molecules ranging from $\sim 600$ 4000 bp were isolated by electroelution. These Sau3A-digested DNA molecules were ligated to BamHI-cleaved pJAS01. The ligation mix was introduced into $S$. lividans by protoplast transformation. Plasmid DNA from several $\beta$-lactamase-positive clones was purified and analysed. The plasmid with the smallest insert size contained a $\sim 1400$ bp BamHI-Sau3A DNA fragment (Fig. 1 b). However, it was later shown by DNA sequencing that the $\sim 1400$ bp BamHI-Sau3A fragment did not encode the complete gene. Therefore, chromosomal DNA of $S$. lavendulae was digested with various restriction enzymes and Southern blot hybridization analysis was done with the $\sim 1400$ bp BamHI-Sau3A fragment as a probe. A $\sim 3200$ bp chromosomal SalI fragment containing the $\beta$-lactamase gene was identified and mapped (Fig. 1b). Sall-digested chromosomal DNA of $S$. lavendulae was separated by electrophoresis on a $1 \%$ preparative GTG agarose gel. DNA molecules ranging from $\sim 2000-6000 \mathrm{bp}$ were isolated by electroelution. This $S a l$ I-digested fractionated chromosomal DNA was ligated into $X$ hoI-cleaved pIJ4642. The ligation mixes were introduced by transformation (Hanahan, 1983) into E. coli DH1. More than $90 \%$ of all tränsformants contained $\mathrm{Sall}$ inserts of chromosomal origin. This genomic library was subjected to colony hybridization screening with the $\sim 1400$ bp BamHI-Sau3A fragment as a probe. Of 1500 colonies, one showed positive hybridization. Analysis of the plasmid of this clone, denoted $\mathrm{p} \beta \mathrm{L}-\mathrm{FLK}-4642$, by restriction-enzyme mapping confirmed that the $\sim 3200$ bp SalI fragment had been cloned. Plasmid DNA of $p \beta L-F L K-4642$ was linearized with $B g / I I$ and ligated to BamHI-digested pJAS01. The recombinant DNA molecules were introduced into protoplasts of $S$. lividans by transformation. After regeneration, the resulting thiostrepton-resistant colonies produced a red zone within $15 \mathrm{~s}$ of addition of nitrocefin.

$D N A$ sequence analysis. The $\beta$-lactamase gene from $S$. badius DSM 40139 was cloned on a $\sim 1300$ bp fragment to plasmid pJAS01 (Jaurin et al., 1988a). The resulting plasmid, denoted $\mathrm{p} \beta \mathrm{B}-1$, was cut with $S p h I / B g l$ II and the fragment carrying the $\beta$-lactamase gene was isolated and purified from a preparative agarose gel. The fragment was first cloned into $S p h \mathrm{I} /$ BamHI-digested pACYC184, followed by insertion into M13 phages mpl8 and mpl9 (Norrander et al., 1983) by utilizing the HindIII site on pACYC184 and the PstI site derived from pJAS01 and the corresponding sites in M13 mp18 and mp19. Also, a number of subfragments of the HindIII-PstI fragment were cloned into M13 phages mp18 and mp19. These subfragment clonings in the M13 phages were a combination of partial Sau3A and directed clonings that together comprised almost the entire $\beta$-lactamase gene. To fill in gaps, sequence specific oligonucleotides were used as primers.

To sequence the $S$. fradiae $\beta$-lactamase gene, the $\sim 1680$ bp $S a l$ I fragment shown in Fig. $1(a)$ was cloned, in both orientations, into SalIdigested M13 mp19. These constructs were digested with $\operatorname{Sacl} / \mathrm{BamHI}$, followed by Exonuclease III and S1-nuclease digestion (Henikoff, 1984). After Klenow treatment, religation and transformation into $E$. coli JM103, templates were prepared from 100-150 bp successive deletions from both orientations. DNA sequence analysis was done as above with M13 universal primer throughout.

To sequence the $S$. lavendulae $\beta$-lactamase gene, various subfragments of the $\sim 1400$ bp BamHI-Sau3A fragment (Fig. $1 b$ ) were cloned into M13 mpl8 and mp19. DNA sequence analysis was done using M13 universal primer. The $\sim 3200$ bp Sall fragment was cloned into M13 mp19, and an oligonucleotide hybridizing close to the Bam HI site was used for sequencing upstream the gene. On the basis of the resulting sequence, another oligonucleotide was synthesized and used to sequence the other strand downstream.

DNA sequence analysis was done using the dideoxy method (Sanger et al., 1977) using deoxyadenosine $5^{\prime}-\alpha-\left[{ }^{35}\right.$ S $]$ thiotriphosphate as label. Both strands were sequenced at least once in every position.

The termination-reaction mixtures were routinely incubated at $37^{\circ} \mathrm{C}$ with Klenow fragment and the terminated products were separated on wedge-shaped $6 \%$ sequencing gels (Sanger et al., 1977). Where compressions were a problem, the sequencing reactions were incubated at $50^{\circ} \mathrm{C}$ with Klenow fragment and the terminated DNA products were separated on wedge-shaped sequencing gels containing $50 \%$ formamide.

Computer analysis. The Geneus sequence-analysis system as well as the programs developed by $\mathrm{R}$. Staden (see Harr et al., 1986) were utilized to assemble and analyse the sequences. The software package PC/Gene, developed by IntelliGenetics, was also used. For multiple amino acid alignments the IntelliGenetics program 'GENALIGN' was used; this program was developed by Dr Hugo Martinez (Sobel \& Martinez, 1986).

\section{Results and Discussion}

\section{DNA sequence analysis of Streptomyces $\beta$-lactamases}

DNA fragments encoding extracellular $\beta$-lactamases of $S$. badius, $S$. cacaoi and $S$. fradiae had been cloned previously (Jaurin et al., 1988a), and the $\beta$-lactamase genes of $S$. badius and $S$. cacaoi subcloned on DNA fragments of $\sim 1300$ and $\sim 1250 \mathrm{bp}$, respectively (Jaurin et al.; 1988a). The subcloning of the $S$. fradiae $\beta$ lactamase gene on a $\sim 1680 \mathrm{bp}$ DNA fragment is described in Methods and Fig. 1(a); the cloning and subcloning of a $\beta$-lactamase gene of $S$. lavendulae is described in Methods and Fig. 1(b). Initially, $\beta$ lactamase activity of $S$. lavendulae was mapped to a $\sim 1400$ bp DNA fragment. Later, we found that this fragment did not encode the whole structural gene; the complete gene was therefore recloned from a genomic library of $S$. lavendulae (see Methods and Fig. $1 b$ ).

The DNA fragments encoding the four $\beta$-lactamase genes were subjected to DNA sequence analysis. We have presented the sequence of the S. cacaoi DSM 40057 gene previously (Forsman et al., 1989), but for comparative purposes it is included here. The high $(73 \mathrm{~mol} \%)$ $\mathrm{G}+\mathrm{C}$ content of Streptomyces (Benigni et al., 1975) results in a highly biased codon usage with a remarkable predominance (more than $90 \mathrm{~mol} \%$ ) of $\mathrm{G}$ or $\mathrm{C}$ in the third and most degenerate position of the translated codons (Bibb et al., 1984). Therefore, the DNA sequences were analysed for open reading frames (ORFs) with such a codon preference at the third position. For each $\beta$-lactamase gene, only one ORF was found that could fulfil this criterion. When ORFs were translated from the first ATG or GTG codon, the primary sequence of $S$. badius and $S$. cacaoi (Fig. 2), and $S$. fradiae and $S$. lavendulae (Fig. 3) $\beta$-lactamases was deduced and found 


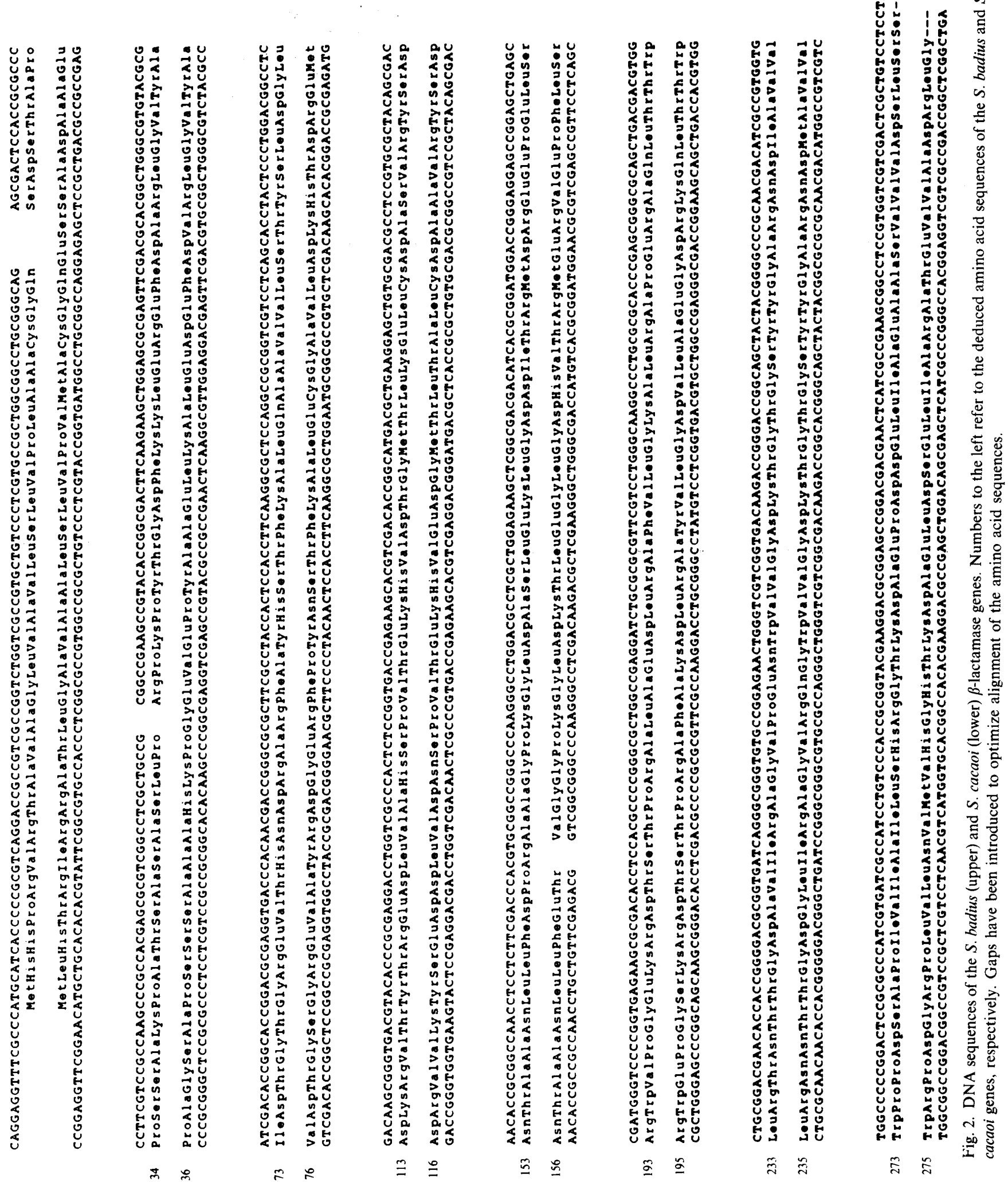




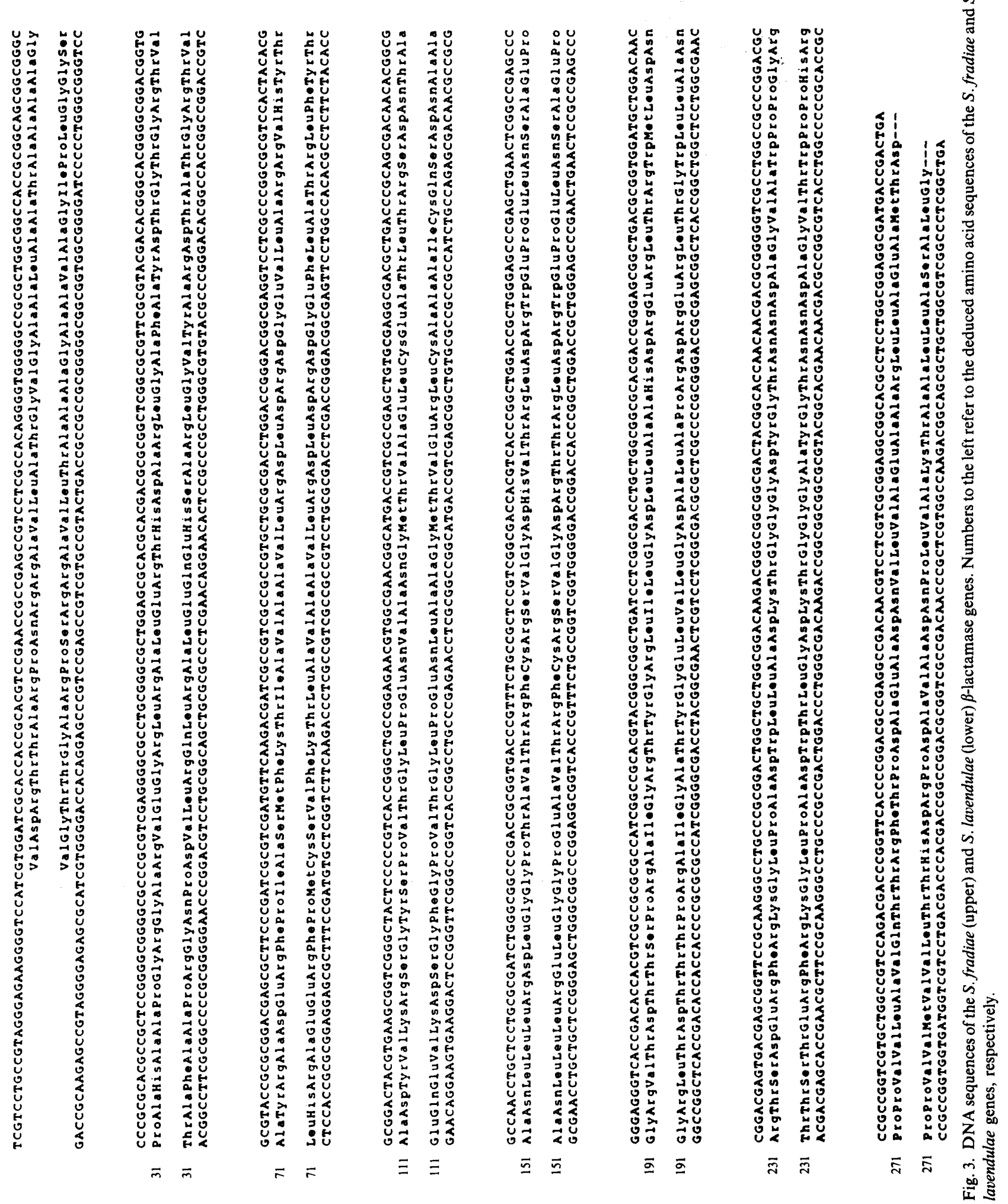


to consist of $313,314,306$ and 305 amino acids, respectively.

The $\mathrm{G}+\mathrm{C}$ content of the $\beta$-lactamase genes of $S$. badius, $S$. cacaoi, $S$. fradiae and $S$. lavendulae was $70 \cdot 7$, $70.7,75.3$ and $74.6 \mathrm{~mol} \%$, respectively, values which are in good agreement with the overall $73 \mathrm{~mol} \% \mathrm{G}+\mathrm{C}$ content of Streptomyces DNA (Benigni et al., 1975). The codon preference for $\mathrm{G}$ or $\mathrm{C}$ at the third position for the four genes was also analysed: it was $94.5 \mathrm{~mol} \%$ for $S$. badius and $S$. cacaoi, $95.6 \mathrm{~mol} \%$ for $S$. fradiae and $94.0 \mathrm{~mol} \%$ for $S$. lavendulae. The codon distribution showed a good correlation with a compilation of codon usages of Streptomyces genes (Hopwood et al., 1986). There was no pronounced preference for $\mathrm{C}$ over $\mathrm{G}$ at third positions when synonymous codons allow such a choice, as was described for the $\alpha$-amylase gene of $S$. limosus (Long et al., 1987). The absence of leucine TTA codons in the four $\beta$-lactamase genes should be noted; it has recently been suggested that the tRNA recognizing this codon is only expressed late in development (Chater et al., 1988). Accordingly, genes that are expressed early should lack this codon. This is in agreement with the observation that $\beta$-lactamases of $S$. badius, $S$. cacaoi and $S$. fradiae are expressed relatively early in growth (Jaurin et al., 1988a). However, the fact that the $a m p C \beta$ lactamase gene of $E$. coli, which has seven TTA codons, is also expressed relatively early in growth when introduced into $S$. lividans (Forsman \& Jaurin, 1987), is intriguing.

DNA sequences just upstream of the coding regions of the $\beta$-lactamases are given in Fig. 4 . When these putative ribosome-binding sites were compared to the sequence close to the 3'-end of 16S rRNA of $S$. lividans (Bibb \& Cohen, 1982), a significant degree of complementarity was observed. As shown in Fig. 4, a four- to six-base-long homology to the complementary sequence of the 3 '-end

\section{s. lividans 5' - AGAAAGGAGGTGATCCAG-3' \\ s. badius $\quad 5^{\prime}$-CGCCAGGAGGTTTCGCCC \\ 5' -GACCCGGAGGTTCGGAAC

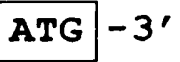 \\ S. cacaoi \\ S. fradiae \\ $5^{\prime}$ - AGGGAGAAGGGGTCCATC \\ 5' - CGTAGGGGAGAGCGCATC
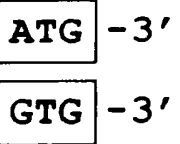 \\ GTG - 3'}

Fig. 4. Ribosomal binding site alignment. The top line shows the complementary DNA sequence of the 3'-end of $S$. lividans $16 \mathrm{~S}$ rRNA. The four sequences below this are the regions upstream from the presumed initiation codon (boxed) of the four $\beta$-lactamase genes examined. Underlined nucleotides show complementarity to the $3^{\prime}$-end of $S$. lividans $16 \mathrm{~S}$ rRNA. of $16 \mathrm{~S}$ rRNA of $S$. lividans was found. These homologous sequence stretches were located seven to eight bases upstream of the respective initiation codon. Many Streptomyces genes do not possess a high degree of complementarity to the 3'-end of 16S rRNA (Hopwood et al., 1986). However, the genes representing the $\beta$ lactamase gene family indigenous to Streptomyces (this paper; Dehottay et al., 1987; M. V. Lenzini \& J. Dusart, personal communication) all show a high degree of complementarity to the ribosomal sequence.

\section{Comparison of amino acid sequences of $\beta$-lactamases}

Table 1 represents the results of a homology search, using the region method of GENALIGN, among the four $\beta$ lactamases reported here, and the $S$. albus $\mathrm{G}$ (Dehottay $e t$ $a l ., 1987$ ) and $S$. cacaoi (Lenzini et al., 1988) $\beta$ lactamases. A homology search was also done with nine non-Streptomyces $\beta$-lactamases, as described in Table 1. Based on the homology scores, the $\beta$-lactamases reported by us could be divided into two groups, with the $S$. badius and $S$. cacao $i$ enzymes in one group, and the $\beta$-lactamases of $S$. fradiae and $S$. lavendulae in the other. This homology was also confirmed at the DNA level by Southern hybridization experiments (Jaurin et al., $1988 b$ ), and in an amino acid sequence homology comparison among the four $\beta$-lactamase genes using the algorithm of Lipman \& Pearson (1985) (data not shown). The $S$. albus $\mathrm{G}$ enzyme (Dehottay et al., 1987) showed strong homology to the second group, and interestingly, the $S$. cacaoi $\beta$-lactamase described by Lenzini et al. (1988) exhibited intermediate homology. However, all six Streptomyces $\beta$-lactamases showed an overall high homology to the class $\mathrm{A} \beta$-lactamases in contrast to the $\beta$ lactamases of classes B, C and D (Table 1). Also, the three class $\mathrm{A} \beta$-lactamases of Bacillus exhibited clustered homology scores, as did the class A Gram-negative $\beta$ lactamases (Table 1).

Obviously, sequence comparison of the $S$. cacaoi $\beta$ lactamase analysed here and the one reported by Lenzini et al. (1988) revealed significant sequence dissimilarities (Table 1). These dissimilarities could be explained by a difference between the strains used or by the presence of two different $\beta$-lactamase genes in the $S$. cacaoi genome. However, fatty acid analysis of the strain used by us, performed by the German Collection of Micro-organisms and Cell Cultures (DSM), showed that the $\beta$ lactamase gene cloned by us originates from the original strain $S$. cacaoi ISP 5057.

Active-site serine $\beta$-lactamases, to which class A enzymes belong, have been shown to possess the consensus sequence Phe- $(\mathrm{X})_{3}$-Ser- $(\mathrm{X})_{2}$-Lys, with the serine as the active site residue (De Meester et al., 1987). This consensus sequence was found in all $\beta$-lactamases 


\section{Table 1. Homology between amino acid sequences of $\beta$-lactamases}

References for sequences are as follows: $S$. badius, S. fradiae and S. lavendulae (this paper); S. albus G (Dehottay et al., 1987); S. cacaoi (this paper and Lenzini et al.; 1988); E. coli TEM-I (no. 11 ; Sutcliffe, 1978); K. pneumoniae (Arakawa et al., 1986); Staph. aureus (Wang \& Novick, 1987); B. licheniformis (Neugebauer et al., 1981); B. cereus type I (Wang et al., 1985); B. cereus type III (Hussain et al., 1987); E. coli ampC (no. 14; Jaurin \& Grundström, 1981); B. cereus type II (no. 13; Hussain et al., 1985); and Sal. typhimurium (Dale et al., 1985). Overall homology scores for pairwise alignment is shown. The scores for every pairwise alignment of the selected sequences are based on the number of matching amino acids and the number of amino acid deletions from the sequences required to keep the common regions in register, as calculated in GENALIGN, using the region method and conservative amino acid replacement alphabet. Boxes indicate groups of highly similar sequences. Repeated randomization of the selected amino acid sequences and subsequent calculation of homology scores, resulted in homology score values between 0 and -100 . Numbers 1 to 12 represent class $A$-lactamases.

\begin{tabular}{|c|c|c|c|c|c|c|c|c|c|c|c|c|c|c|c|}
\hline & 1 & 2 & 3 & 4 & 5 & 6 & 7 & 8 & 9 & 10 & 11 & 12 & 13 & 14 & 15 \\
\hline $\begin{array}{l}\text { 1. S. badius } \\
\text { 2.S. cacaoi (this paper) } \\
\text { 3. S. fradiae } \\
\text { 4. S. lavendulae } \\
\text { 5. S. albus } \\
\text { 6. S. cacaoi (Lenzini et al., 1988) } \\
\text { 7. B. licheniformis } \\
\text { 8. B. cereus type I } \\
\text { 9. B. cereus type III } \\
\text { 10. Staph. aureus } \\
\text { 11. E. coli TEM-1 } \\
\text { 12. } \text {. pneumoniae } \\
\text { 13. B. cereus class B } \\
\text { 14. E. coli class C } \\
\text { 15. Sal. typhi. class D }\end{array}$ & & 211 & $\begin{array}{l}137 \\
137\end{array}$ & $\begin{array}{r}123 \\
128 \\
230\end{array}$ & $\begin{array}{r}143 \\
138 \\
209 \\
209 \\
\end{array}$ & $\begin{array}{l}147 \\
131 \\
128 \\
126 \\
121\end{array}$ & $\begin{array}{l}168 \\
151 \\
136 \\
131 \\
120 \\
102\end{array}$ & $\begin{array}{r}173 \\
162 \\
132 \\
118 \\
124 \\
122 \\
181\end{array}$ & $\begin{array}{l}159 \\
142 \\
132 \\
121 \\
131 \\
109 \\
207 \\
175 \\
\end{array}$ & $\begin{array}{r}117 \\
106 \\
90 \\
89 \\
80 \\
106 \\
135 \\
126 \\
117\end{array}$ & $\begin{array}{r}100 \\
108 \\
126 \\
119 \\
95 \\
101 \\
105 \\
110 \\
90 \\
106\end{array}$ & $\begin{array}{r}94 \\
102 \\
119 \\
119 \\
95 \\
88 \\
103 \\
106 \\
89 \\
104 \\
201 \\
\end{array}$ & $\begin{array}{r}-56 \\
-57 \\
-48 \\
-48 \\
-26 \\
-46 \\
-39 \\
0 \\
-23 \\
0 \\
-24 \\
-22\end{array}$ & $\begin{array}{l}-64 \\
-63 \\
-28 \\
-72 \\
-63 \\
-74 \\
-70 \\
-71 \\
-61 \\
-96 \\
-91 \\
-92 \\
-120\end{array}$ & $\begin{array}{r}-29 \\
-39 \\
-31 \\
-12 \\
-39 \\
-8 \\
-2 \\
-3 \\
-18 \\
-2 \\
-2 \\
1 \\
-1 \\
-102\end{array}$ \\
\hline
\end{tabular}

reported here, as well as those reported previously (Fig. 5 ). Thus it seems likely that the $\beta$-lactamases described by us are representatives of active-site serine $\beta$ lactamases, as has been shown for the $S$. albus $\mathrm{G}$ enzyme (De Meester et al., 1987) and the E. coli TEM-1 $\beta$ lactamase (Fisher et al., 1981).

Streptomyces $\beta$-lactamases are extracellular enzymes (Ogawara, 1981). When cells of $S$. lividans containing the cloned $\beta$-lactamases of $S$. badius, $S$. cacaoi, $S$. fradiae and $S$. lavendulae were grown, the majority of the enzyme activity was secreted (Jaurin et al., 1988a; data not shown). This indicated that these enzymes should be synthesized in a precursor form containing an $\mathrm{NH}_{2}$ terminal signal peptide, as are most extracellular proteins of Streptomyces (Hütter \& Eckhardt, 1988). Using the method of von Heijne (1986), the cleavage site between the signal peptide and the mature protein of the four $\beta$-lactamases was predicted (Fig. 6). Based on this analysis, both $S$. badius and $S$. cacaoi $\beta$-lactamases contained signal peptides 26 amino acids long. Predicted signal peptides of the $S$. fradiae and $S$. lavendulae enzymes were 34 amino acids long. All four signal peptides conformed to the criteria characteristic of such sequences: a hydrophilic amino terminus containing charged amino residues such as arginine; a central hydrophobic transmembrane region; and the -1 to -3 cleavage site rule (von Heijne, 1986). The lengths of signal peptides vary, e.g. 18 to 25 for $E$. coli and 30 to 40 for Bacillus; for Streptomyces signal peptides the range is much wider, from 24 to 56 amino acid residues (Hütter \& Eckhardt, 1988). The four predicted $\beta$-lactamase signal peptides (Fig. 6) also conform to the notion that Streptomyces signal peptides have a predominance of arginine residues as charged residues in the hydrophilic part of the signal peptide, whereas lysine residues are preferred by $E$. coli or Bacillus (Hütter \& Eckhardt, 1988).

The roles of $\beta$-lactamases in Streptomyces are not completely known (Ogawara, 1981). Whereas $\beta$-lactamases cause drug resistance in pathogenic bacteria, a change in target specificity is the main resistance mechanism in Streptomyces (Ogawara, 1981). It has been suggested that $\beta$-lactamases in Streptomyces are ancestors of those in pathogenic bacteria (Ogawara, 1981). The class A Bacillus $\beta$-lactamase group showed higher similarities to $\beta$-lactamases of Streptomyces than to $\beta$ lactamases of the enterobacteria (Table 1). The $\beta$ lactamase of Staphylococcus aureus exhibited highest homology to the Bacillus group, and somewhat lower homology to the $\beta$-lactamases of Streptomyces and the enterobacteria (Table 1). The class A $\beta$-lactamases were aligned and divided in twenty amino acid windows and compared (Fig. 7). A high overall homology was found. Three regions that were highly conserved among the $\beta$ - 

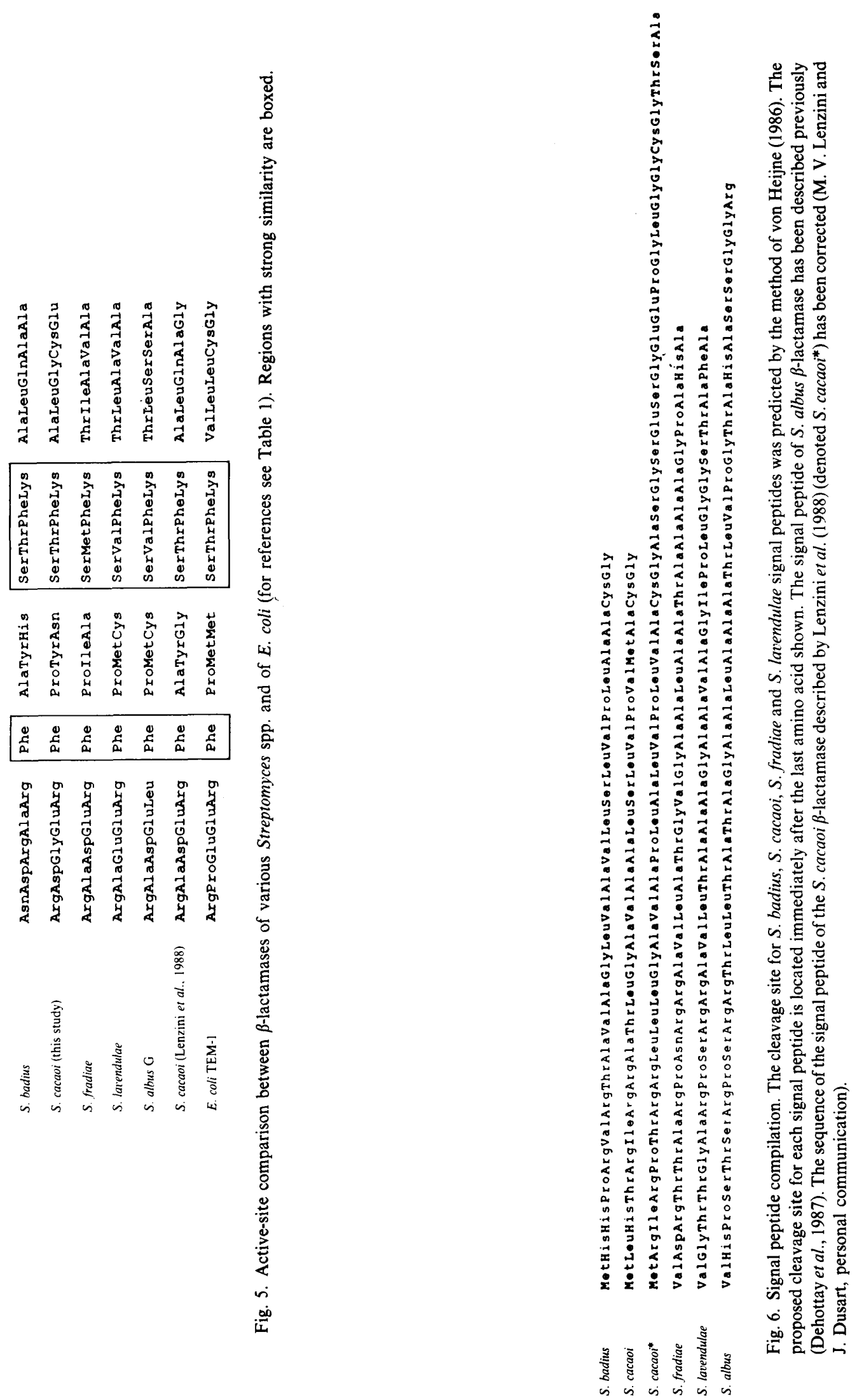


S. cacaoi (Lenzini et al., 1988)
S. fradiae
S. lavendulae
S. albus
S. badius
S. cacaoi (this paper)
B. cereus type I
B. licheniformis
B. cereus type III
Staph. aureus
E. coli
K. pneumoniae

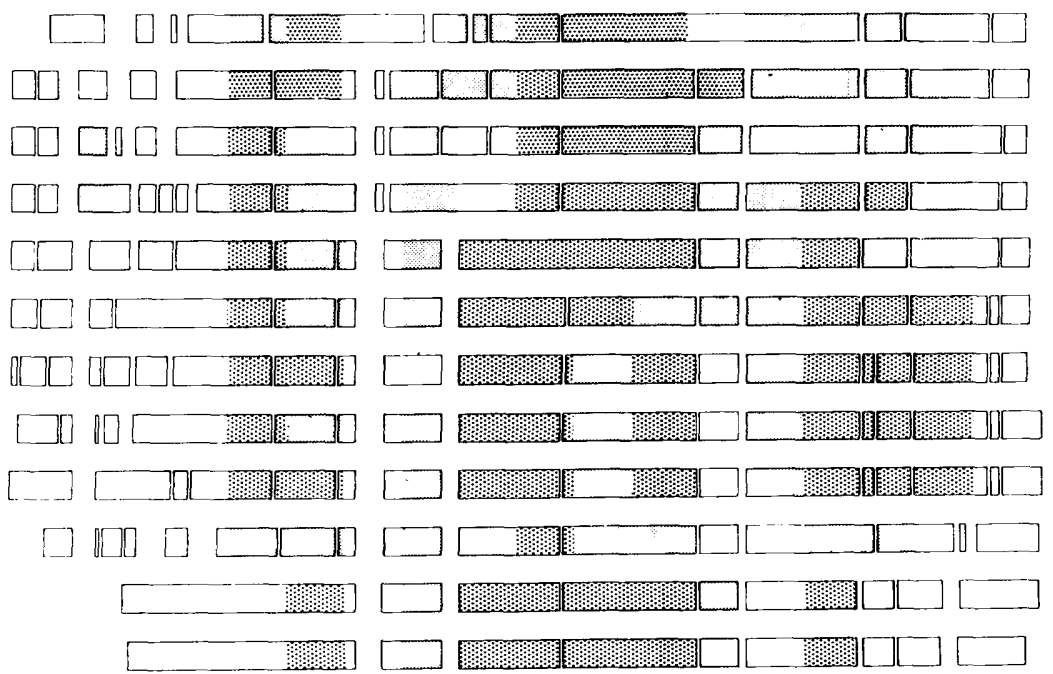

Fig. 7. Alignment of the amino acid sequences of class $A \boldsymbol{\beta}$-lactamases (for references see Table 1). Optimal alignment of the sequences was achieved using the program GENALIGN (Sobel \& Martinez, 1986). The alignment was done using the Jimenez-Montano and Zamora-Cortina conservative amino acid replacement alphabet. Each sequence was divided into successive 20 amino acid windows. Every window was compared with the amino acid consensus sequence derived from the alignment. Homology was defined as identity plus conservative replacements of amino acids. The windows are represented as follows: open boxes represent $0-9$ amino acid homology to the consensus sequence; light-grey boxes indicate 10-14 amino acid homology to the consensus; and stippled boxes show 15-20 amino acid homology to the consensus sequence. I, II and III indicate conserved regions, and correspond to positions 61-99, 110-208 and 225-301, respectively, of the precursor of the $S$. albus G $\beta$-lactamase (Dehottay et al., 1987).

lactamases could be identified. The first conserved block spanned the active-site region, the second was located in the middle of the primary sequence and the third conserved block was found at the C-terminus (Fig. 7). The Gram-positive class A $\beta$-lactamases exhibited a similar pattern of conserved segments in these three regions. However, the two enterobacterial class A $\beta$ lactamases showed a lack of homology to the Grampositive class $\mathrm{A}$ enzymes in the region preceding the active site and in the C-terminus region. This probably indicates that these regions are not essential for a functional $\beta$-lactamase, and therefore have not been under evolutionary constraint. Also, we suggest that Streptomyces class A $\beta$-lactamases are representatives of a Gram-positive superfamily of genes, from which class A $\beta$-lactamases of Gram-negative bacteria may have evolved.

This work was in part supported by a Swedish Medical Research Council grant (no. B88-16X-7171-4A). We acknowledge Maria Westling for assistance in preparation of the manuscript, Gunnar Boström for artwork, Dr T. Kieser for providing plasmid pIJ4642, Dr D. A. Morrison for reading of the manuscript, and Dr A. Akkermans for participation in the initial cloning of the $S$. lavendulae $\beta$-lactamase gene.

\section{References}

AMBler, R. P. (1975). The amino acid sequence of Staphylococcus aureus penicillinase. Biochemical Journal 151, 197-218.
Ambler, R. P. (1980). The structure of $\beta$-lactamases. Philosophical Transactions of the Royal Society B289, 321-331.

Ambler, R. P. \& SCOTt, G. K. (1978). Partial amino acid sequence of penicillinase coded by Escherichia coli plasmid R6K. Proceedings of the National Academy of Sciences of the United States of America 75, 3732-3736.

arakawa, Y., Ohta, M., Kido, N., Fujil, Y., Komatsu, T. \& Kato, N. (1986). Close evolutionary relationship between the chromosomally encoded $\beta$-lactamase gene of Klebsiella pneumoniae and the TEM $\beta$-lactamase gene mediated by R plasmids. FEBS Letters 207 , 69-74.

Benigni, R., Antonov, R. P. \& Carere, A. (1975). Estimate of the genome size by renaturation studies in Streptomyces. Applied Microbiology 30, 324-326.

Bertani, G. (1951). Studies on lysogenesis. I. The mode of phage liberation by lysogenic Escherichia coli. Journal of Bacteriology 62, 293-300.

BiBb, M. J. \& Cohen, S. N. (1982). Gene expression in Streptomyces: construction and application of promoter-probe plasmid vectors in Streptomyces lividans. Molecular and General Genetics 18, 265-277.

BibB, M. J., Freeman, R. F. \& Hopwood, D. A. (1977). Physical and genetical characterization of a second sex factor, SCP2, for Streptomyces coelicolor A3(2). Molecular and General Genetics 154, 155-166.

BibB, M. J., Findlay, P. R. \& Johnson, M. W. (1984). The relationship between base composition and codon usage in bacterial genes and its use for the simple and reliable identification of protein-coding sequences. Gene 30, 157-166.

Chang, A. C. Y. C. \& Cohen, S. N. (1978). Construction and characterization of amplifiable multicopy DNA cloning vehicles derived from p15A cryptic miniplasmid. Journal of Bacteriology 134, 1141-1156.

Chater, K. F., Lawlor, E. J., Mendez, C., Bruton, C. J., Davis, N. K., Plaskitt, K., Guthrie, P., Daly, B. L., Baylis, H. A. \& Vu TronG, K. (1988). Gene expression during Streptomyces develop- 
ment. In Biology of Actinomycetes '88, pp. 64-70. Edited by $Y$. Okami. T. Beppu \& H. Ogawara. Tokyo: Japan Scientific Press.

Citri, N. (1971). Penicillinase and other $\beta$-lactamases. In The Enzymes, vol. 4 , pp. $23-26$. Edited by P. Boyer. New York: Academic Press.

Dale, J. W., Godwin, D., Mossakowska, D., Stephenson, P. \& WALL, S. (1985). Sequence of the OXA-2 $\beta$-lactamase :.comparison with other penicillin-reactive enzymes. FEBS Letters 191, “39-44:

Dehottay, P., Dusart, J., De MeEster, F., Joris, B., VAN BeEumen, J., Erpicum, T., Frere, J.-M. \& Ghuysen, J.-M. (1987). Nucleotide sequence of the gene encoding Streptomyces albus $\mathrm{G} \beta$-lactamase precursor. European Journal of Biochemistry 166, 345-350.

De Meester, F., Joris, B., Lenzini, M. V., DehotTay, P., Erpicum, T., Dusart, J., Klein, D., Ghuysen, J.-M., Frere, J.-M. \& Van BEEUMEN, J. (1987). The active sites of the $\beta$-lactamase of Streptomyces cacaoi and Streptomyces albus G. Biochemical Journal 244, 427-432.

Fisher, J., Charnas, R. L., Bradley, S. M. \& Knowles, J. R. (1981). Inactivation of the RTEM $\beta$-lactamase from Escherichia coli. Interaction of penam sulfones with enzyme. Biochemistry 20, 27262731.

Forsman, M. \& JAURIN, B. (1987). Chromogenic identification of promoters in Streptomyces lividans by using an ampC $\beta$-lactamase promoter-probe vector. Molecular and General Genetics 210, 23-32.

Forsman, M., Lindgren, L., Häggström, B. \& JaURin, B. (1989). Transcriptional induction of Streptomyces cacaoi $\beta$-lactamase by a $\beta$ lactam compound. Molecular Microbiology 3, 1425-1432.

HaNAHAN, D. (1983). Studies on transformation of Escherichia coli with plasmids. Journal of Molecular Biology 166, 557-580.

HaRR, R., Fällman, P., HÄGGSTRÖM, M., WAHLSTRöM, L. \& Gustafson, P. (1986). Geneus, a computer system for DNA and protein sequence analysis containing information retrieval system for the EMBL library. Nucleic Acids Research 14, 273-283.

vON HEIJNE, G. (1986). A new method for predicting signal sequence cleavage sites. Nucleic Acids Research 14, 4683-4690

HENIKOFF, S. (1984). Unidirectional digestion with exonuclease III creates targeted breakpoints for DNA sequencing. Gene 28, 351-359.

Hopwood, D. A., BibB, M. J., Chater, K. F., Kieser, T., Bruton, C. J., Kieser, H. M., Lydiate, D. J., Smith, C. P., Ward, J. M. \& SCHREMPF, H. (1985). Genetic Manipulation of Streptomyces: A Laboratory Manual. Norwich, UK: John Innes Foundation

Hopwood, D. A., Bibb, M. J., Chater, K. F., Janssen, G. R., Malpartida, F. \& Smith, C. P. (1986). Regulation of gene expression in antibiotic-producing Streptomyces. Symposia of the Society for General Microbiology 39, 251-276.

Huovinen, P., Huovinen, S. \& Jacoby, G. A. (1988). Sequence of PSE-2 $\beta$-lactamase. Antimicrobial Agents and Chemotherapy 32, 134 136.

Hussain, M., Carlino, A.. Madonna, M. J. \& Lampen, J. O. (1985). Cloning and sequencing of the metallothioprotein $\beta$-lactamase II gene of Bacillus cereus $569 / \mathrm{H}$ in Escherichia coli. Journal of Bacteriology 164, 223-229.

Hussain, M., Pastor, F. I. J. \& Lampen, J. O. (1987). Cloning and sequencing of the $b l a Z$ gene encoding $\beta$-lactamase III, a lipoprotein of Bacillus cereus 569/H. Journal of Bacteriology 169, 579-586.

HÜTTER, R. \& ECKHARDT, T. (1988). Genetic manipulation. In Actinomycetes in Biotechnology, pp. 89-184. Edited by M. Goodfellow, S. T. Williams \& M. Mordarski. London: Academic Press.

JAURIN, B. \& CoHEN, S. N. (1984). Streptomyces lividans RNA polymerase recognizes and uses Escherichia coli transcriptional signals. Gene 28, 83-91.

JAURIN, B. \& GRUNDSTRÖM, T. (1981). ampC cephalosporinase of Escherichia coli $\mathrm{K}-12$ has a different evolutionary origin from that of $\beta$-lactamases of the penicillinase type. Proceedings of the National Academy of Sciences of the United States of America 78, 4897-4901.

JAURIN, B., ForSMAN, M. \& HÄGGSTRÖM, B. (1988a). B-Lactamase genes of Streptomyces badius, Streptomyces cacaoi and Streptomyces fradiae, cloning and expression in Streptomyces lividans. Biochimica et Biophysica Acta 949, 288-296.

Jaurin, B., Forsman, M., Häggström, B. \& Lindgren, L. (1988b). Molecular aspects of extracellular $\beta$-lactamases of Streptomyces. In Biology of Actinomycetes '88, pp. 457-462. Edited by Y. Okami, T. Beppu \& H. Ogawara. Tokyo: Japan Scientific Press.
Knott-Hunziker, V., Petursson, S., Jayatilake, G. S., Waley, S. G., Jaurin, B. \& GRUndström, T. (1982). The chromosomal $\beta$ lactamases of Pseudomonas aeruginosa and Escherichia coli. Biochemical Journal 201, 621-627.

Lenzini, M. V., Ishihara, H., Dusart, J., Ogawara, H., Joris, B., van Beeumen, J., Frere, J.-M. \& GhuYSEN, J.-M. (1988). Nucleotide sequence of the gene encoding the active-site serine $\beta$ lactamase-from Streptamyces cacaoi. FEMS Microbiology Letters 49, $371-376$.

Lipman, D. J. \& PEARSON, W. R. (1985). Rapid and sensitive protein similarity searches. Science 227, 1435-1441.

Lomovskaya, N. D., Mkrtumian, N. M., Gostimskaya, N. L. \& DANILENKo, V. N. (1972), Characterization of the temperate actinophage $\phi \mathrm{C} 31$ isolated from Streptomyces coelicolor A3(2). Journal of Virology 9, 258-262.

long, C., Virolle, M.-J., Chang, S.-Y., Chang, S. \& Bibb, M. J. (1987). The $\alpha$-amylase gene of Streptomyces limosus: nucleotide sequence, expression motifs and amino acid sequence homology to mammalian and invertebrate $\alpha$-amylases. Journal of Bacteriology 169, 5745-5754.

Maniatis, T., Fritsch, E. F. \& SambrooK, J. (1982). Molecular Cloning. A Laboratory Manual. Cold Spring Harbor, NY: Cold Spring Harbor Laboratory.

Neugebauer, K., Sprengel, R. \& Schaller, H. (1981). Penicillinase from Bacillus licheniformis: nucleotide sequence of the gene and implications for the biosynthesis of a secretory protein in a Grampositive bacterium. Nucleic Acids Research 9, 2577-2588.

Norrander, J., Kempe, T. \& Messing, J. (1983). Construction of improved M13 vectors using oligodeoxynucleotide-directed mutagenesis. Gene 26, 101-106.

O'Callaghan, C. H., Morris, A., Kirby, S. M. \& Shingler, A. (1972). Novel method for detection of beta-lactamases by using a chromogenic cephalosporin substrate. Antimicrobial Agents and Chemotherapy 1, 283-288

OGawaRA, H. (1981). Antibiotic resistance in pathogenic and antibiotic-producing bacteria, with special reference to $\beta$-lactam antibiotics. Microbiological Reviews 45, 591-619.

SANGer, F., Nicklen, S. \& Coulson, A. R. (1977). DNA sequencing with chain terminating inhibitors. Proceedings of the National Academy of Sciences of the United States of America 75, 5463-5467.

Sobel, E. \& Martinez, H. M. (1986). A multiple sequence alignment program. Nucleic Acids Research 14, 363-374.

SutCliffe, J. G. (1978). Nucleotide sequence of the ampicillin resistance gene of Escherichia coli plasmid pBR322. Proceedings of the National Academy of Sciences of the United States of America 75, 3737-3741

ThATChER, D. R. (1975). The partial amino acid sequence of the extracellular $\beta$-lactamase I of Bacillus cereus $569 / \mathrm{H}$. Biochemical Journal 147, 313-326.

ThOMPSON, C. J., WARD, J. M. \& HoPWOOD, D. A. (1980). DNA cloning in Streptomyces; resistance genes from antibiotic-producing species. Nature, London 286, 525-527.

WANG, P.-Z. \& Novick. R. P. (1987). Nucleotide sequence and expression of the $\beta$-lactamase gene from Staphylococcus aureus plasmid p1 258 in Escherichia coli, Bacillus subtilis and Staphylococcus aureus. Journal of Bacteriology 169, 1763-1766.

Wang, W., Mézes, P. S. F., Yan, Y. Q., Blacher, R. W. \& Lampen, J. O. (1985). Cloning and sequencing of the $\beta$-lactamase gene of Bacillus cereus 5/B and its expression in Bacillus subtilis. Journal of Bacteriology 163, 487-492.

WARD, J. M., JANSSEN, G. R., Kieser, T., BibB, M. J., ButTner, M. J. \& BiBB, M. J. (1986). Construction and characterization of a series of multi-copy promoter-probe plasmid vectors for Streptomyces using the aminoglycoside phosphotransferase gene Tn5 as indicator Molecular and General Genetics 203, 468-478.

Yamamoto, S. \& Lampen, J. O. (1976). Purification of plasma membrane penicillinase from Bacillus licheniformis $749 / \mathrm{C}$ and comparison with exoenzyme. Journal of Biological Chemistry 251, 4095-4101.

Yanisch-Perron, C., Vieira, J. \& Messing, J. (1985). Improved M13 phage cloning vectors and host strains: nucleotide sequences of the M13 mp18 and pUC19 vectors. Gene 33, 103-119. 